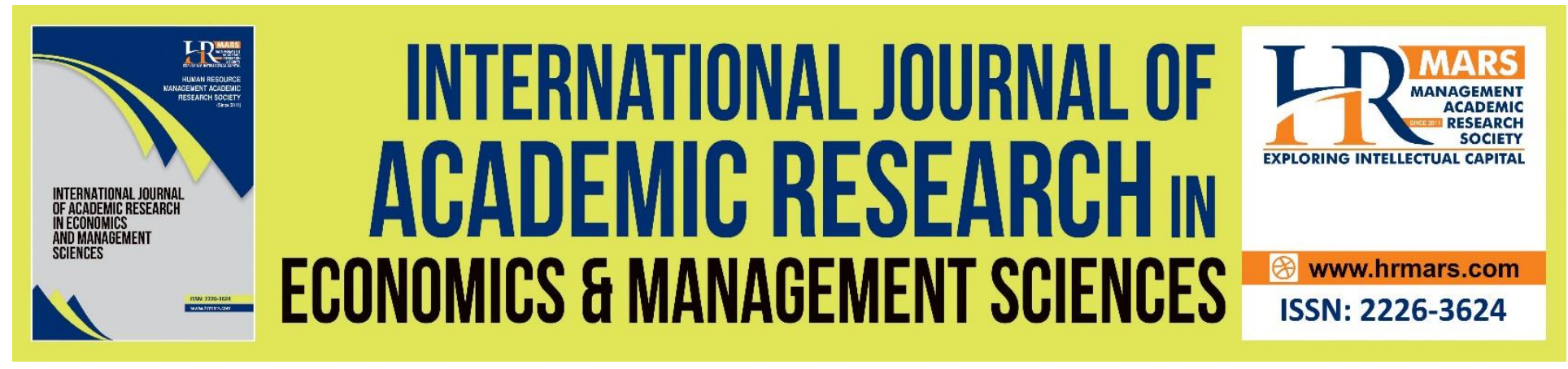

\title{
The Impact of Strategic Planning on the Performance of Governmental Organizations: An Empirical Study on Oman's Five-Year Plan (2011-2015)
}

Mohammed Hatem Jan Al-Balushi, Mooi Wah Kian and Midya Yousefi

To Link this Article: http://dx.doi.org/10.6007/IJAREMS/v10-i3/11314

DOI:10.6007/IJAREMS/v10-i3/11314

Received: 01 July 2021, Revised: 24 July 2021, Accepted: 20 August 2021

Published Online: 15 September 2021

In-Text Citation: (Al-Balushi et al., 2021)

To Cite this Article: Al-Balushi, M. H. J., Kian, M. W., \& Yousefi, M. (2021). The Impact of Strategic Planning on the Performance of Governmental Organizations: An Empirical Study on Oman's Five-Year Plan (2011-2015). International Journal of Academic Research in Business and Social Sciences, 10(3), 314-339.

Copyright: (C) 2021 The Author(s)

Published by Human Resource Management Academic Research Society (www.hrmars.com)

This article is published under the Creative Commons Attribution (CC BY 4.0) license. Anyone may reproduce, distribute, translate and create derivative works of this article (for both commercial and non-commercial purposes), subject to full attribution to the original publication and authors. The full terms of this license may be seen at: http://creativecommons.org/licences/by/4.0/legalcode

Vol. 10, No. 3, 2021, Pg. 314 - 339 


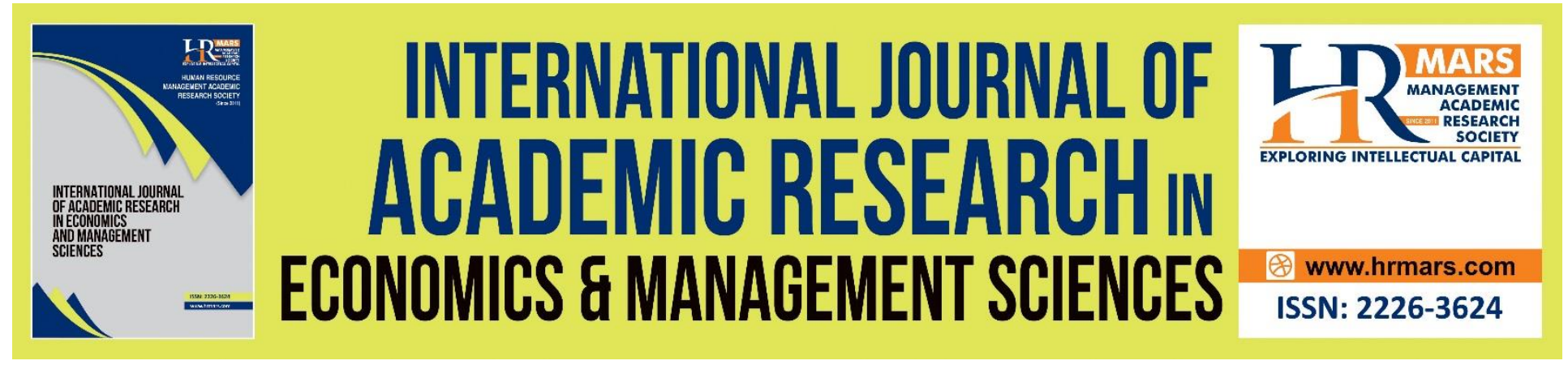

\title{
The Impact of Strategic Planning on the Performance of Governmental Organizations: An Empirical Study on Oman's Five-Year Plan (2011-2015)
}

\author{
Mohammed Hatem Jan Al-Balushi ${ }^{1}$, Dr Mooi Wah Kian² and Dr \\ Midya Yousefi ${ }^{3}$ \\ ${ }^{1} \mathrm{PhD}$ Researcher, Binary University of Management \& Entrepreneurship, Malaysia, ${ }^{2}$ Professor, \\ Infrastructural University of Kuala Lumpur and ${ }^{3}$ Senior Lecturer, Binary University of \\ Management \& Entrepreneurship
}

\begin{abstract}
The current study concentrates on investigating the impact of strategic planning including the "existing of strategic base, strategy comprehensiveness, extent of planning, strategy effectiveness and ongoing evaluation" on the performance of governmental organizations in the Sultanate of Oman through an empirical study on the five-year plan (2011-2015) of the state. The population of the study include all managers, heads and members who work in planning departments at eight selected governmental ministries of civil service representing the government sector organizations in the sultanate of Oman. The population of the study estimated at 425 employees, using Yamane's (1967) formula and the sample size estimated by 207 employees covering employees from all the eight selected ministries representing $56.4 \%$ of the total population. By analyzing Spearman's Correlation Coefficients between independent variables and dependent variable the results indicate that the overall strategic planning significantly correlated with the outcome variable which is the performance of government organizations. Consequently, the current study proves that the performance of government organizations positively influenced by strategic planning factors expressed by the "extent of planning, comprehensiveness of strategy, the effectiveness of the strategy, existing of strategic base and ongoing evaluation". As well as, study findings confirm that strategic planning is essential for governmental organizations, that because it provides a sense of direction and outlines measurable objectives. Thus, strategic planning uses for guiding day-to-day decisions, evaluating the progress of the organization and changing approaches when moving forward. In the aim to make the most of strategic planning the organization must give careful thought to the strategic objectives it outlines, and then back up these objectives with realistic, thoroughly researched, quantifiable benchmarks for evaluating results. In the end, the results of the current
\end{abstract}


study contribute to persuading the government of the Sultanate of Oman about the importance of applying strategic planning in all its governmental agencies.

Keywords: Strategic Planning, Government Organizations, Performance and Five-Year Plans.

\section{Introduction}

This research is a comprehensive study about the impact of strategic planning on the performance of governmental organizations in the sultanate of Oman. It is important to examine the extent of strategic planning factors that influence the governmental organization performance in the local government organizations. It is hoped that the output of this study will be beneficial to all parties concerned, while at the same time contribute to knowledge enhancement in the academic world. In a global environment that accelerated economic, social, political and cultural changes, the organizational development in government organizations in Oman needs to manage themselves in a modern, purposeful and conscious management style that can overcome the challenges they may face in the strategic phases of action, to move them to an advanced stage to increase their chances of success and to fulfill their roles as best as possible through the application of strategic planning. The strategic planning has great importance in developing the capacities of government organizations in the Sultanate of Oman and the five-year plans of the state. The importance of understanding the strategic planning process for the government sector in Oman which represented by the service ministries helps government organizations to adapt to their surrounding environment and to improve their performance in order to achieve optimum performance. Therefore, the strategic planning keeps Omani government organizations focusing on their goals and helps them in organizing the total work, with allocates resources in an effective and efficient way. So, the government organizations that are well planning can perform better than those are not planning properly. Accordingly, strategic planning gives government organizations a clear direction and a clear road map. The issue of strategic planning still requires conducting further studies because of the novelty of the topic in Omani context and its importance in the events of development events and the desired change (Harrasi et al., 2019). Whereby previous studies on the Omani context have shown the positive relationship between strategy and organizational performance (Kenny and Mwangi, 2017; Saidi, 2010). The authorities in Oman have already made some crucial steps in involving the strategic planning in the day to day running of affairs (Mukrashi, 2016). As gargantuan efforts were deployed to improve basic living conditions, authorities realized that Oman needs longrange planning and, towards that end, adopted the five-year plans. By 1975, the government had allocated resources for its first five-year plan to finance the construction of 1500 houses for lowincome Omanis (Joseph, 2008). The Sultanate of Oman is a country enhance the development by planning for all its functions and objectives. Since the new era, the government relies in completion of its target objectives on strategies and annual plans of the state. Accordingly, in 2012 the sultanate created the supreme council for planning as an organization for the purpose of follow up its strategies and plans.

\section{Literature Review}

\section{Sultanate of Oman}

Oman is one of the Oldest Human-Inhabited Places on the Earth. People lived in what is currently known as sultanate of Oman for no less than 106,000 years and the city of Al-Dereaze is no less 
than 9,000 years of age. Oman Was Once Colonized by the Portuguese at the point when the Portuguese entered the Indian Ocean exchange, they pined for the port of Muscat and assumed control over the Omanis for just about 150 years until neighborhood tribesman drove them out in 1650, now Oman is currently the oldest independent state in the Arab World. Oman was the primary Arab countries to perceive the United States as a free country. Worth mentioning terrorism and the terrorist assaults are nonexistent in Oman. The Global Terrorism Index (GTI) reports that Oman is a nation in the area where terrorism has had no effect (Kenny and Mwangi, 2017). The Sultanate of Oman is strategically country placed at the entrance of the Gulf at the south-east corner of the Arabian Peninsula and is located between Latitudes 16' 40' and 26' 20' North and Longitudes 51' 50' and 59' 40' east. It has a coastal line extending along $3165 \mathrm{~km}$, from the "Strait of Hormuz" in the North to the borders of the Republic of Yemen, and overlooking three seas; the Arabian Gulf, Oman Sea, and the Arabian Sea (BBC News, 2017). Oman contiguous the United Arab Emirates, Saudi Arabia, and Yemen. It is 309,500 square kilometers, and it is the third-largest country in the Arabian Peninsula, with a population of 4,441,448 at the end of 2016. However, nearly 1998650 of them, which represent 45\%, are expatriates. Today, Oman is a modern monarchy ruled by His Majesty Sultan Qaboos with a bicameral legislature, and the nation's capital is Muscat. Full suffrage is granted to all Omanis over the age of 21 to elect one of two governing councils in the state, as well as the women, who play an active role in every facet of Omani life. Adult literacy is more than $75 \%$, and Arabic is the official language; besides, the English language plays a crucial role in higher education and private sector institutions, although many languages are spoken. Islam is the sole religion for Omanis and a source of legislation for the Basic Statute of the State (Sultan Qaboos Cultural Center, 2017). The state divided into nine administrative regions (four governorates, five regions), which are further sub-divided into sixtyone (61) districts. Each Wilayat is governed by a Wali who is responsible to the Ministry of Interior (Oman Information Center, 2001). Oil and gas are the main resources for the economy. Still, Oman has a number of natural resources, including petroleum, copper, asbestos, marble, limestone, gypsum, and frankincense, where the agriculture and fisheries play an important role in the economy and always been a part of the traditional way of life in Oman (Alkaabi et al., 2019; Supreme Council for Planning, 2016). The year 2015 was an important year of development planning for the Omani Government, with key work undertaken not only on the development of the long-term vision of Oman 2040 but also on the Ninth Five Year Plan or Ninth National Development Plan (NDP) 2016-2020. This has led all ministries to prepare forward-looking strategic inputs to these vital plans (UNICEF, 2015). According to the report of UBHAR Capital it is optimistic about the economic situation of Sultanate of Oman in light of a focused development plans, the prioritization of public investment, the draft foreign investment law, push to the growth of SME's and concerted effort on the diversification plan (UBHAR Capital, 2017).

\section{Government Sector in Oman}

The successive development plans set by the government included many developmental goals that stem from the requirements of each stage of natural development and progressive growth in the various economic and social sectors. The first major phase of 1970-1995 began, which included four consecutive five-year development plans each plan will achieve specific development goals. The second phase of 1996 to 2020 covered a comprehensive and future vision for the Omani economy in light of the new global concepts such as market economics, 
globalization and other global economic realities, which must be dealt with to the maximum potential. In line with the economic development, there was a clear interest in modernizing and developing the administrative apparatus of the state by focusing on administrative development on the path of comprehensive national development. The law regulating of administrative apparatus of the state was issued by Royal Decree No. 26/75, which defines the terms of reference of the Council of Ministers and Specialized Councils, followed by another civilizational shift in the Civil Service Law promulgated by Royal Decree No. (27/75) as a law regulating the rights and duties of civil servants to launch the real start of the administrative development process in the Sultanate (ARADO portal, 2001). The administrative system consists of the Diwan of Royal Court, the Ministry of Palace Office, the Cabinet of Ministers, the Specialized Councils, the Governorates and the Council of Oman (Majlis Oman). The Cabinet of Ministers considered as a highest executive authority, deriving its power from His Majesty the Sultan, to whom it is collectively responsible, whereas laws, decrees, international treaties, agreements and charters are authorized by His Majesty Sultan Qaboos. In order to create the opportunity for the Oman's citizens to participate in country's government efforts a Consultative Council was established, where the Oman Chamber of Commerce and Industry represents the private sector and the remainder by the Government of Oman. The tasks of the council a forum for the combined efforts of the government and people's constituencies wherein they may undertake to study the aims of the development plan. "The white book" this most important piece of legislation was enacted in 1996. The purpose of the basic statute of the state is to provide a force for political and social stability, while at the same time guaranteeing the rights and freedoms of the individual. Besides laying down a procedure for the succession to the throne, the statute provided for the formation of a State Council of Oman. It is a comprehensive document defining the role of Government and the judiciary, as well as laying down the policy if state towards the economy, security, education and social development of the nation (Oman Information Center, 2001). Through the review of the organizational structure of the government sector in Oman which done in 31st December 2016 illustrated that the number of government civil organizations in Oman is 61 organizations, 38 of them under the supervision of the civil service system, while 23 of the civil service organizations are ministries. In 1970 the total number of Civil Service employees was 1,750 of which (1630) were Omanis, and (120) were Expatriates. Within the end of 2016, the total number of Civil Service employees was (177717) of which (154512) were Omanis, representing (86.9\%) and (23205) were Expatriates, representing (13.1\%) of the total. Compared to the year 2015, the number of Omani employees decreased by (1249), also the number of Expatriates decreased by (1420) and they concentrated in educational services, medical, public health and their related support jobs. Women working at the Civil Services units constituted (48\%) of the total number of employees, and during the last five years, this percentage witnessed as increase indicating more empowerment of women and more women participation in society development. Most of Civil Service employees were concentrated in the Ministry of Education and the Ministry of Health representing $(69 \%)$ of the total (Ministry of civil services, 2017).

\section{Master Strategies and Plans in Oman}

In order to achieve the goal of human and social development in all areas of the Sultanate, we have instructed our government to focus, in its future plans, on social development, particularly its aspects related to the daily lives of citizens. In order to promote human and social 
development in all regions of the Sultanate, the government-endorsed a set of national strategic plans, which are to deliver the services people need to their areas: the government has endeavored to find strategic plans that contribute to developing the fields of education, health, training, and employment (Sultan Qaboos speech, 2012). Therefore, the table (1) sheds lights on general on the main strategies and plans adopted by the Supreme Council for Planning in the sultanate of Oman and in particular it will focus on the five-year plans in the sultanate of Oman (SCPOMAN, 2016).

Table (1) shows the adopted strategies in Oman

$\begin{array}{llcc}\text { No } & \text { The Strategy } & \text { Start } & \text { End } \\ 1 & \text { Five-year plans of the state } & 1976 & \text { Every five Years } \\ 2 & \text { Vision for Oman economy 2020 } & 1996 & 2020 \\ 3 & \text { Vision for Oman economy 2040 } & 2021 & 2040 \\ 4 & \text { Long term strategy for tourism } & 2015 & 2040 \\ 5 & \text { National strategy of statistics and information } & 2006 & 2020 \\ 6 & \text { National program (TANFEEDH) } & 2016 & 2020\end{array}$

Source: (SCPOMAN, 2016)

\section{Five-Year Plans}

The development strategies which have been adopted within the early stage of the Omani renaissance period can be viewed as an attempt to lay the foundations which would provide the conditions and climate for rapid development of the five-yer plans within the country. Efforts were concentrated on the determination of areas of most urgent need and the provision of the infrastructure necessary for economic growth. Major objectives included the development of production, increasing the national income and the establishment of the fundamental basis for the foundation of a modern economic society (Al-Mashrafi, 2002). The five-year plans of the state could be introduced as a comprehensive national strategy for long-term development, including the future vision and general directions of the State (Royal Decree No. 30/2012). The Omani government pursues the principle of five-year plans since the first five-year plan (1976-1980) whilst we are in the ninth five-year plan (2016-2020), where the current study concentrates on examining the impact of strategic planning on government performance through the eighth fiveyear plan (2011-2015). The Eighth Five Year Plan focus on diversifying the sources of economic income for the Sultanate of Oman and to support the stability and growth of the national economy in particular (Ahmed, 2011). It seeks to realize on annual growth rates of not less than $3 \%$ at constant prices and at a rate of $6 \%$ at current prices, provided that the annual average rate of inflation for the plan period is about $4 \%$ (Arabian Business, 2011). It gives priority in allocating government expenditure to provision of social services in terms of health, general education, housing, water and sanitary drainage services beside development of oil and gas sectors. Promote opportunities of sustainable tourism development to achieve economic with more efforts to encourage internal tourism, intensifying abroad touristy promotion. Pay special 
attention to the development of the sectors of agriculture and fisheries to promote food security (Supreme Council for Planning, 2011).

\section{Performance}

Since the primary goal of any organization is to achieve its goals and objectives besides the increasing organizational performance (Kabiru et al. 2018) thus the performance described as an organization's ability to utilize its resources as possible in achieving its operational goals (Abdalkrim, 2013), as its the total economic results of the activities undertaken by an organization (Akinyele et al 2010). The performance can be defined as multidimensional entity, should be linked with the desired outcomes which measured throughout productivity, effectiveness, efficiency and quality (Alalade \& Oguntodu, 2015). The Organizational performance is described as an organization's ability to acquire and utilize its resources and valuables as possible in the following up of its operational goals (Alkaabi et al., 2020; Stegerean et al., 2011). And therefore, the concept of performance become essential to all type of organization that because the major objective of businesses is to make profits (Mutindi, 2015). It's also the primary aim of any organization is to achieve its goals and objectives which are making the best profit by increasing organizational performance (Latif et al., 2012). Also, the performance defined in term of the efficiency of the process of an organization and the total economic results of the activities undertaken by an organization (Odhiambo and Waiganjo, 2014). It could be described as a formula for the assessment of the functioning of an organization under certain criteria such as productivity, employee morale and effectiveness with the aim of achieving sustainable competitive advantage (Fwaya, 2006). While there is empirical support for a positive relationship between strategic planning and performance, there is also evidence suggesting that no such relationship exists. This dichotomy has hindered the development of this important research domain. The empirical studies investigating a direct relationship between strategic planning and performance have attracted criticisms, including the use of a bivariate methodology. While this relationship is of importance to organizations practicing strategic planning, the critics suggest that other factors will impact on the relationship between strategic planning and performance (Rudd et al., 2008).

\section{Strategic Planning}

One of the most crucial activities in management is planning. In the aim to determine where the organization is going, whether it operates in the private or in the public sector. And it is differentiated from other pre-decision activities, in that it is systematic, deliberate, and continuous (Glaister and Richard, 1999). As well the strategic planning is widely used by organizations at the international level, as it is an integral part of a strategy and it's a formal consideration of an organization's future course (Bradford and Duncan, 2000). As well given that strategic planning's unique purpose is to improve strategic performance, the improving, assessing, and monitoring effectiveness of the strategic planning would seem to be an important managerial task (Paul and Moutinho, 1999). Also in traditional, the strategic planning executives had a five to ten year penetrating for planning, whereas the current technologies and the rapid development in the world do traditional strategic planning in a difficult situation (Zuckerman A. M., 2000). As well can be said that the strategy is a dynamically changing set of integrated plans that happen over a period of time instead of merely a paperwork exercise completed once a year 
(Mintzberg, 2007). Strategic planning for nearly 50 years has been a standard feature of management thinking and practice in the business world, and for more than 25 years, it has become the standard practice of large numbers of public and non-profit organizations (Bryson, 2004). Thus the efficacy of strategic planning in relation to the level of uncertainty. Therefore, they explained uncertainty as a variable in strategic planning, and they identified the levels of uncertainty around both internal and external forces for change as a deterrent to the efficacy of strategic planning in the traditional concept (Courtney et al., 1997). The strategic planning as organizational activity logically discuss mission and goals, also inspect the competitive environment, analysis strategic alternatives, and coordinate actions of implementation through the whole organization (Andersen, 2000). It seeks to evaluate environmental threats and opportunities in the context of strengths and weaknesses. Therefore, the outcome is an action plan of how the organization will capitalize on its strengths and weaknesses to achieve its mission (Ernest Ofori, 2006). As well it is an organizational management process used to analyze the current situation of an entity, to determine priorities, and to focus resources and energy on achieving and maintaining a competitive advantage for the entity itself (Cara Ong, 2015).

\section{Importance of Strategic Planning}

The importance of strategic planning lies in providing workers in organizations with the opportunity to participate in the decision-making process that gives them a sense of satisfaction and commitment. As well as to achieve the ability to coordination between the various activities, and commitment to the strategic objectives set by the organization. It's also trying to minimize the negative effects of the surrounding circumstances, identify the opportunity that available to contribute to the effectiveness of the organization and provide a framework for rationalizing management in making good decisions (Zaibi, 2014). The importance of strategic planning is also represented that it is a roadmap to the success, developing a holistic vision of the organization, setting specific goals for achievement, clarifying the strengths and weaknesses of the organization, providing accurate information that helps in the decision-making process (Attieh, 2014). Therefore, the importance of strategic planning is highlighted by the challenges facing organizations today in accelerating quantitative and qualitative change in the business environment, increasing competition between institutions, global openness, lack of sovereignty between countries, technological change and decreasing resources. Other equally important challenges, such as transformation from industrial societies to knowledge and technology societies, and the instability in future situations (Khaled et al., 2019; Yasin and Ghaleb, 1998). There is broad agreement among leaders and experts that planning is an important element of good management. Where the planning assure that the organization remains connected and responsive to the needs of its community, and participate to organizational stability and growth. It also provides a foundation for monitoring progress, and assessing results and impact. It facilitates new program development, and it enables an organization to look into the future in an orderly and systematic way (McKay, 2001).

\section{Obstacles to Strategic Planning}

The strategic planning focusing on the key strategic challenges that must address to sustain their success into the future. Therefore, a huge contributor to the challenge facing when implementing the strategic planning. So, the management has to actively engage in every step when 
implementing the strategic planning (Jamadar et al., 2021; Njeri, 2016). Companies design their strategy to resolve the casual problems and not by focusing on fundamental problems. It concluded that the common planning and strategy barriers including companies do not contain sustainability in their vision and policies, as well as the lack of human resources and lack of departments for sustainability (Isaka et al., 2010). Study has been conducted in South Africa, found out that the prominent challenges to implementation of strategies was the resistance to the change, poor financing, poor strategic planning and poor evaluation (Mpofu, 2010). In addition to that, the poor financing, poor attitude, poor planning and poor implementation and evaluation are the most hindrances of strategy (Alshamsi, et al., 2019; Mashavira \& Nyanga, 2013). Furthermore, the most challenges are facing the implementation of strategic planning in governmental organizations are the management commitment which plays an important role in implementing the strategic plans, it also the resource scarcity hinders the implementation of strategic planning process (Njeri, 2016). Some pitfalls that must avoid it to be closer to your goal, perhaps achieve better results and improve your business. As well as your organization can create an effective strategic plan process, and it can build a realistic business trend for the future, and greatly improve the opportunity for successful implementation of your strategy. Don't have a plan just for plans sake like most everything in the life; pay attention to understanding the business environment, set meaningful priorities, and understand the need to pursue results (Aileron, 2011). There are several challenges facing the strategic planning in developing countries, which are summarized in finding data as an actual challenge that facing the strategic planning, because available statistics are far below than those available (Sameh, 2006). When the leaders do not support the plan, it will fail and when there is a lack of consensus there will be an inevitable political fight. As well as too ambitious and extremely motivated people set tough strategic planning objectives. Likewise, the failures happen when the strategic plan is so far away from the actual life of the organization. Finally, when the process takes too long time, then those involved begin to lose their drives, therefore clients typically advised to consider a three to fiveyear plan that because ten years are too far (Haden, 2010). According to the literature review, the researcher believes that strategic planning can be divided into independent variables which could have an impact on the performance of the government organizations which is chosen as the dependent variable. Based on the theoretical models the researcher could construct a sample model for the strategic planning in order to explore and test the relationship among variables in order to solve the particular research problem, reach the research objectives and answer the research questions. Therefore, the major variables of strategic planning that will be tested in theoretical models are: Existing of Strategic Base, Strategy Comprehensiveness, "Extent of Planning, Strategy Effectiveness, Ongoing Evaluation and Performance. The five year plans selected to represent the areas of strategic planning in the Omani government sector. The principle of five-year plans in Oman adopted by the government since 1976 and the first five-year plan was in (1976 - 1980), whilst we are now in the ninth five-year plan (2016-2020). Based on strategic planning Models (Suri \& Sushil, 2017; Salkic, 2014; Boyd and Reuning-Elliott's, 1998) the current study develops a research model to investigate the impact of strategic planning on the government performance. 


\section{Extent of Planning}

The Extent of Planning shows a depth of coverage of different elements in the planning process, the involvement of stakeholders in planning, service orientation of project plan and the possibility of modifying an approved project plan as suggested by program planning methodology for complex projects (Hill and Warfield, 1972). As well as, it encompasses measures that coverage program planning elements including important aspects of project planning such as affected societal sectors, essential needs, constraints, alterable, objectives, objective measures, activities, activity measures and agencies involved (Suri and Sushil, 2017). Nevertheless, its concern with the involvement of stakeholders in planning comprises the extent to which project-specific stakeholders are involved in the planning process. Noteworthy, the timelines for services is crucial which encompasses service orientation of the project plan, i.e. whether the timelines for gradually inserting more services for beneficiaries are defined in the plan. Likewise, the modifiable project plan also is significant through the adaptability of the planning process, i.e. the extent to which an approved plan is changeable to face the future changes.

\section{Strategy Comprehensiveness}

Strategy Comprehensiveness concerns with the strategy formulation-related aspects which are considered essential for the realization of governmental planning (Suri and Sushil, 2017). These elements are viewed as the involvement of stakeholders in strategy formulation, the provision for stakeholders' concerns and redefining of roles and responsibilities through defining of roles of concerned actors and assignment of new tasks to them as part of the project plan. As well as provision for obtaining feedback by dealing with importance given to capturing feedback from actors belonging to the different departments having the service, officials at headquarters, external actors in other related organizations and project beneficiaries (David, 2011). Strategy formulation begins with the development of long-range plans for the effective management of environmental opportunities and threats in light of corporate strengths and weaknesses. It includes defining the corporate mission, specifying achievable objectives, developing strategies and setting policy guidelines. The simplest way of environmental analysis is through SWOT analysis, which is the method to analyze the strengths and weakness in order to utilize the threat and to overcome the threat (Thenmozhi, 2014).

\section{Strategy Effectiveness}

Strategy Effectiveness is worth mentioning that experience shows that there are four key success factors that have to be balanced in implementing a strategy philosophy which is the management commitment, focusing on measurable and actionable improvement, the employee involvement and learning. Strategic planning and management participation enhance the effectiveness of strategic planning (Batra, 2016). This strategy effectiveness is viewed as to what extent the existing operational environment assist the realization of the crafted strategy. It is designed to cover of aspects such as involvement of stakeholders in the strategy implementation, the involvement of senior leadership and review of implementation from top-level, effective communication of strategy, empowerment of operational crew, and the motivation of employees (Suri and Sushil, 2017). The improved effectiveness of strategic planning may drive to improved performance (Paul and Moutinho, 2000). The effective implementation of the strategic plan required pragmatism, flexibility, opportunism and the commitment and participation of 
employee at all organizational levels to provides a solid base for future evidence for this approach (Garth et al., 2008).

\section{Existing of Strategic Base}

Existing of Strategic Base explained by the organization's strategic vision, mission statement, written short-term goals, and long term goals (Salkic, 2014). Accordingly, the major question here is: why and where to organizational mission include the identity and the core competence of the organization and indicates its existence reasons. Therefore, the mission is not linked to the time because the effective formulated mission creates unambiguous behavior of employees, strengthens one-mindedness, and improves the internal communication and the atmosphere within the organization (Rampersad, 1997). The organizational mission and vision together form a significant management instrument that expresses the soul of the institution and indicates what the organization stands for, for which purpose it existed, what its primary goals are. They give direction to organization and functions as a road map and persuasive propagation of an active, inspiring, recognizable, challenging, and fascinating mission and vision which touch people and create feelings of solidarity usually lead to more effort, satisfaction, and commitment. After all, such a common ambition inspires creativity, motivates and mobilizes people, gives them energy, and leads to better performances (Hamel and Prahalad, 1994).

\section{Ongoing Evaluation}

Ongoing Evaluation it is the last stage in the strategic planning to ensure that announced objectives are being done (Kriemadis, 1997). Ongoing Evaluation is a regular review of an organization's short and long-term plans, including analysis of results, to evaluate progress and determine if modifications are needed (Campbell, 2010). Often organizations shy away from the process of evaluating their strategy because they're scared of uncovering the depth of their 'failure'. It's not so much about success or failure - rather it's about continual improvement and self-awareness. That's why strategy evaluation is important to your continued growth as an organization and how you did (Wright, 2019). Thus, every organization must constantly review the implementation process, assess progress, and make decisions related to corrective action. The assessing areas of work, research, and service for achieving goals and realizing the mission is the absolute measure of (Brewer et al., 2000). Boyd and Reuning-Elliott (1998) developed a multidimensional model which included seven planning activities: mission statement, trend analysis, competitor analysis, long-term goals, annual goals, short-term action plans, and ongoing evaluation, then conducted two studies to successfully test their model. Using the Boyd and Reuning Elliot's (1998) model, Baker and Leidecker (2001) found that organizations in have a positive association between performance and the degree of emphasis on several planning tools, with the highest associations noted for use of mission statements, long-term goals, and ongoing evaluation (Sullivan, 2006).

\section{The Necessity of Government's Strategic Planning}

The public or government sector is the major actor in macro socio-economic policy making infrastructure and architecture for enabling the environment of national development. Anyways as a result, the public sector must be more successful in order to facilitate the success of the private sector in the country and the fulfillment of theme of the national development plan and 
the realization (Kihanya, 2013). The strategic planning provides workers with the opportunity to participate in the decision-making process that gives them a sense of satisfaction. As well as to achieve the ability to coordination between the various activities, and commitment to the strategic objectives set by the organization (Zaibi, 2014). The grand promise of strategic planning for public management is to enable public sector organizations to manage the interrelationships and interconnectedness between the various internal and external organizational factors in order to improve the quality of life of people and enhance public value (Rosenbloom, 1998). In the public sector organizations, however, those in executive positions often have their powers constrained by statute and regulation which predetermine, to various degrees, not only the very purpose of the organization but also their levels of freedom to diversify or to reduce, for example a loss-making service (Duncan, 1990). The strategic thought increasingly become important to the continued viability and effectiveness of governments. As well without strategic planning it is unlikely that government organizations going to able to meet successfully the challenges that face them. As well the environments of public and government organizations have changed dramatically as a result of oil crises, demographic shifts, changing values, taxing limits, privatization, centralization or decentralization of responsibilities, information revolution and service-based economics, change in macroeconomic performance (Bryson, 1988). The environment of public sector organizations is changing continuously; this change has a profound impact on public organizations and how they are managed to handle change. Therefore the top management adapts to the changing environment that reflect on its ability to deal successfully with unpredictable external and internal events, and with the help of strategic planning, governments, communities and public organizations have dealt with change and adapted to it, because the strategic planning is intended to strengthen an organization's capacity to adapt to change and to enhance the ability of an organization's members to think, act, and learn strategically (Bryson, 2004). The Government leaders have become gradually interested in strategic planning since the early 1970 s as a consequence, of the wrenching changes that have overthrown the public sector (Eadie, 1983). Strategic planning became a common practice in governments and nonprofit organizations. The practice has become widespread for many reasons, but the main one is the evidence that strategic planning typically works and extremely well. Improvements in strategic planning practice are likely to come as it is seen and researched in its full richness as a practice, or set of practices. As well over the last 25 years, strategic planning has become a ubiquitous practice in governments and non-profit organizations. Experience demonstrates that strategic planning can be used successfully by public agencies and organizations, general purpose governments (city, county, state), public and non-profit organizations which providing essentially public services (Bryson, 2010). The initiation of strategic planning primarily includes a series of three simple activities for many governmental organizations; gathering of key actors and key decision makers, to work through a strategic thinking and acting process, in order to focus on what is exactly important for the organization, to identify priorities for action and to generate those actions. Might these activities conceptually be simple, and quite difficult to implement because the initiation of strategic planning is a process directly designed to produce change (Bryson and William, 1988). 


\section{Conceptual Framework}

The conceptual framework indicates a graphical representation of the theorized interrelationships of variables of the study (Odhiambo \& Waiganjo, 2014). As well as it has further explained the sub-variables to be tested in each variable which are the measures that will be tested in the survey questionnaire (Ranjit Kumar, 2011). It's also helping in identifying factors and variables associated with the research study; through bringing dependent, independent and moderating variables together into a theoretical model (Sagaran, 2017). The conceptual framework of the current research study as a basic model, which has been developed based on the theoretical framework and previous studies in the field of strategic planning and organizational performance with some modification of variables to be adapted to fit the Omani government organizations context through the eighth five-year plan of the state 2011-2015. The developed conceptual model of the current study shows how the researcher theorizes the relationships among various factors selected as being important to the research questions. The conceptual framework draws on the reviews of previous theories and models to discuss the interrelationships among the variables that are thought to be integral to the concepts of the situation being investigated. The developed conceptual model will help suppose appropriate propositions to test certain relationships among variables and thus improve Omani government employees to understand the phenomena under study. However, for the purpose of the current study, a detailed examination of different variables associated with the research topic in hand is needed to satisfy the objectives of this study. According to review theories and models of strategic planning, there are several variables of strategic planning influencing organizational performance and contribute to the success of public organizations. These include linking strategies with achieving institutional goals, enhance efficiency and improve quality of service as well as many other factors.

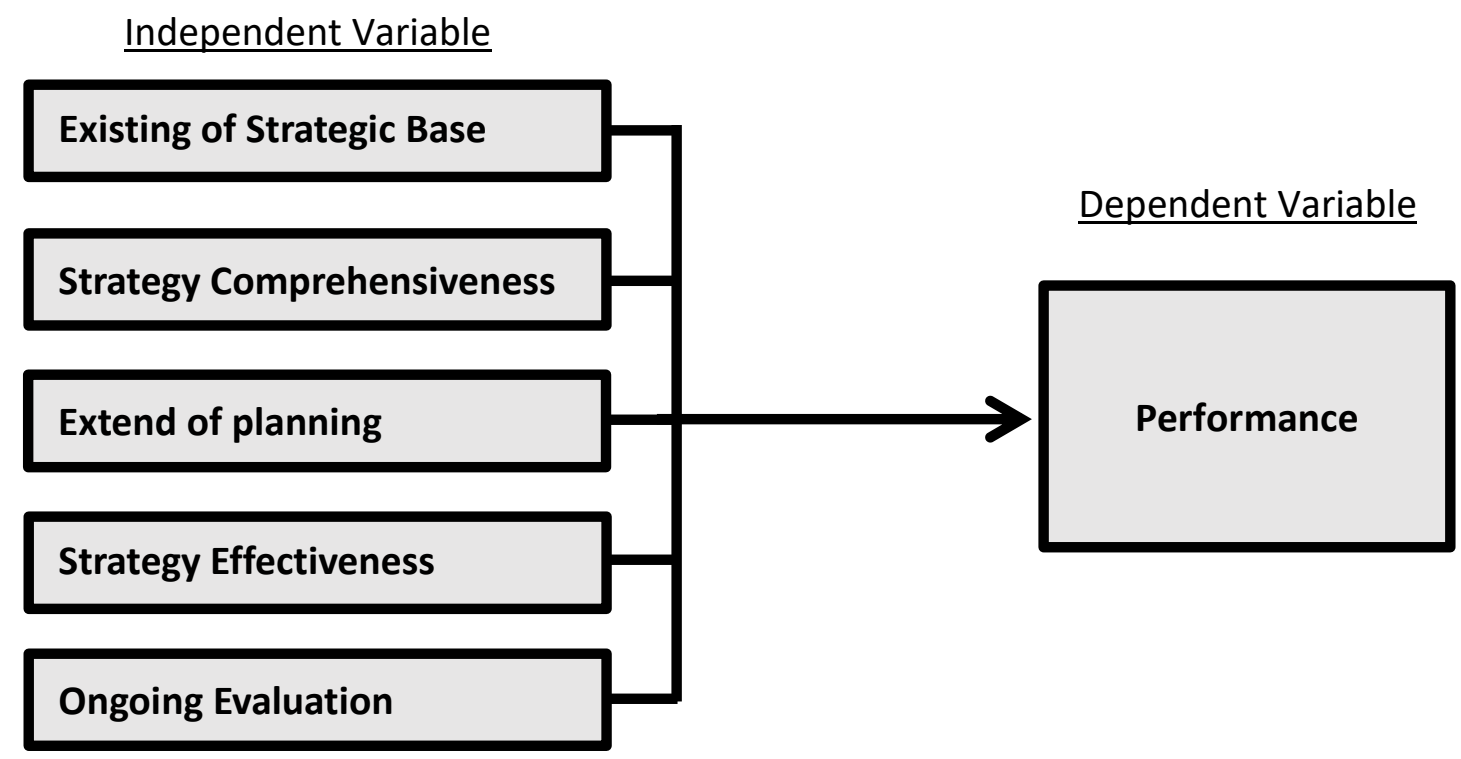

Figure 1 The Conceptual Framework. Source: Author, January 2020 


\section{Variables}

Variables of the conceptual model are: Existing of strategy Base, Strategy comprehensiveness, Extent of planning, Strategy effectiveness and Ongoing Evaluation that represent the independent variables while the dependent variable is the Performance.

\section{Hypotheses}

$\mathrm{H}_{1}$ : There is a significant relationship between "existing of strategic base" and performance of government organizations in Oman.

$\mathrm{H}_{2}$ : There is a significant relationship between "strategy comprehensiveness" and performance of government organizations in Oman.

$\mathrm{H}_{3}$ : There is a significant relationship between "extent of planning" and performance of government organizations in Oman.

$\mathrm{H}_{4}$ : There is a significant relationship between "strategy effectiveness" and performance of government organizations in Oman.

$\mathrm{H}_{5}$ : There is a significant relationship between "ongoing evaluation" and performance of government organizations in Oman.

\section{Methodology}

The current study methodology determined in line with the research strategy and methods of collecting and analyzing the required data. Accordingly, in the aim of collecting descriptive data for a quantitative study a positivist philosophy adopted for the current study in order to investigate the impact of strategic planning on performance. The positivist philosophy is an epistemological position that calls for working with observable social phenomena, which represented in activities engaged during the strategic planning in government organization (Saunders et al., 2009). As well the deductive approach is adopted to because the topic and the conceptual framework are drawn from earlier studies about strategic planning impact on performance (Sue Greener, 2008; 16). Whenever the topic is new the more appropriate to work inductively (Saunders et al., 2009; 124). Due to the type of study variables and descriptiveanalytical method this research will be studied as a quantitative research method. Since this research is following the quantitative research method the researcher used a survey strategy as a data collecting tool, by distributing a questionnaire composed of closed-ended questions. For this research study time horizons, the researcher will use the cross-sectional time horizon for the collection of the data as against of longitudinal time horizon. According to the population of the study that included in this research the simple random sampling adopted as a technique for selecting the required sample size, where the individual of the population has the same chance or probability of being selected as sample subjects (Geoffrey et al, 2005). The Population of this study is limited in the Sultanate of Oman, Muscat Governorate, government organizations which represented in ministries of the government sector. This study has been conducted on eight selected ministries which are associated with the completion of Oman's five-year plans. The population for this study covers all managers, heads and members who are working in the planning departments at the eight selected ministries. Accordingly, the population estimated by 425 employees, using Yamane's (1967) formula the sample size estimated by 207 employees, covering employees from all the eight selected ministries, which representing $56.4 \%$ of the total population. 


\section{Statistical Methods Used for Data Analysis}

1. Data analysis done via SPSS and Excel software program.

2. The reliability of the measurement tool assessed by Cronbach's Alpha and Split-Half Method.

3. Questionnaire Part one: descriptive statistical analysis of the general information of study sample were found by frequencies and percentiles.

4. Questionnaire Part two: descriptive statistical analysis of strategic planning and performance found by percentiles, means, standard deviations, satisfaction level and order.

5. Kurtosis and skewness test, for normality of distribution.

6. In order to test the relationship between independent variables and dependent variables, the researcher used the Spearman Brown Correlation, which is a non-parametric test.

7. Linear Regression Analysis is estimating equation that predicts values for a dependent variable from the values of independent variables.

According to table (2) the current study uses the Five Likert Scale Item as a tool to examine how strongly subjects agree or disagree with statements of the questionnaire. The respondents will be asked to score the (27) paragraphs which are representing the five axis about the strategic planning and one axis about the performance. Questions on a five Likert points scale (strongly agree, agree, don't know, disagree, strongly disagree), to explore the strategic planning impact on performance of the Omani government sector, through the five year plans. The researcher chose grade (1) to respond "to a very small degree", so that the relative weight in this case is $20 \%$ and it is proportional to this response.

\begin{tabular}{|c|c|c|c|c|c|}
\hline \multicolumn{7}{|c|}{ Table (2) Questionnaire Items Measure } \\
\hline Score & 1 & 2 & 3 & 4 & 5 \\
\hline Classification & $\begin{array}{c}\text { Strongly } \\
\text { Disagree }\end{array}$ & Disagree & Don't Know & Agree & $\begin{array}{c}\text { Strongly } \\
\text { Agree }\end{array}$ \\
\hline
\end{tabular}

As the questionnaire's responses are scored in a five point Likert scale (ranging from strongly disagree $=1$, to strongly agree $=5$ ) evaluation criteria for judging the level of respondents' scores (respondents' attitudes levels) were developed. Table (3) illustrates the means' groups and the decision beside each group.

\begin{tabular}{|l|c|c|c|}
\hline \multicolumn{4}{|c|}{ Table (3) Evaluation Criteria used for measuring attitudes' levels } \\
\hline Likert Scale & Score & Means & Decision \\
\hline Strongly Disagree & 1 & $1-1.79$ & Very low \\
\hline Disagree & 2 & $1.8-2.59$ & Low \\
\hline Don't Know & 3 & $2.6-3.39$ & Medium \\
\hline Agree & 4 & $3.4-4.19$ & High \\
\hline Strongly Agree & 5 & $4.2-5$ & Very high \\
\hline
\end{tabular}

Table (4) shows the measure of internal consistency, the Cronbach's Alpha: a coefficient of 0.70 and above is considered acceptable. The recommended ceiling is 0.90 and anything higher especially above 0.95 could infer items are repeated, hence without any increase in internal 
consistency. Cronbach's Alpha can also take low or even negative values for otherwise a valid test. The low value can be due to low number of questions, poor inter-relatedness between items or heterogeneous (multiple factors) constructs and negative value due to (Reverse Coding) (Sagaran, 2017).

Table (4) the measure of internal consistency

\begin{tabular}{|c|c|}
\hline Cronbach's Alpha & Internal consistency \\
\hline$a \geq 0.9$ & Excellent \\
\hline $0.7 \leq a<0.9$ & Good \\
\hline $0.6 \leq a<0.7$ & Acceptable \\
\hline $0.5 \leq a<0.6$ & Poor \\
\hline$a<0.5$ & Unacceptable \\
\hline
\end{tabular}

Table (5) shows reliability of the instrument, the overall Cronbach's Alpha value was 0.932 , which suggests an excellent level of reliability of the questionnaire. The overall Guttmann Split-Half Coefficients value was (0.980) which suggests a very good level of internal consistency of the questionnaire.

\begin{tabular}{|l|l|l|l|l|l|}
\hline \multicolumn{5}{|c|}{ Table (5) Cronbach's Alpha values for each dimension of the questionnaire } \\
\hline $\begin{array}{l}\text { No } \\
.\end{array}$ & Dimension & $\begin{array}{l}\text { Cronbach' } \\
\text { s Alpha }\end{array}$ & $\begin{array}{l}\text { No } \\
.\end{array}$ & Dimension & $\begin{array}{l}\text { Split-Half } \\
\text { Coefficient }\end{array}$ \\
\hline 1 & Extent of Planning & 0.698 & 1 & Extent of Planning & 0.831 \\
\hline 2 & $\begin{array}{l}\text { Strategy's } \\
\text { Comprehensiveness }\end{array}$ & 0.648 & 2 & $\begin{array}{l}\text { Strategy's } \\
\text { Comprehensiveness }\end{array}$ & 0.703 \\
\hline 3 & Strategy's Effectiveness & 0.670 & 3 & Strategy's Effectiveness & 0.674 \\
\hline 4 & $\begin{array}{l}\text { Existing of Strategic } \\
\text { Base }\end{array}$ & 0.590 & 4 & Existing of Strategic Base & 0.652 \\
\hline 5 & Ongoing Evaluation & 0.978 & 5 & Ongoing Evaluation & 0.953 \\
\hline 6 & Performance & 0.963 & 6 & Performance & 0.980 \\
\hline Overall questionnaire & 0.932 & \multicolumn{2}{|l|}{ Overall questionnaire } & 0.900 \\
\hline
\end{tabular}

Table (6) Kurtosis and skewness, the values of Kurtosis and skewness used to test the normality of data distribution, while average skewness and kurtosis have values of 1.13 and 1.61, and the high skewness and kurtosis have a value of 1.8 and 3.8 (Donald and Pamela, 2014). The result of Skewness and kurtosis test for the given data shows that data not normally distributed since data should be at 0 for normal distribution. 
INTERNATIONAL JOURNAL OF ACADEMIC RESEARCH ECONOMICS AND MANAGEMENT SCIENCES Vol. 10, No. 3, 2020, E-ISSN: 2226-3624 @ 2020 HRMARS

\begin{tabular}{|l|c|c|c|c|c|c|}
\hline \multicolumn{7}{|c|}{ Table (6) Kurtosis and Skewness Test } \\
\hline & $\begin{array}{c}\text { Extent of } \\
\text { Planning }\end{array}$ & $\begin{array}{c}\text { Strategy's } \\
\text { Comprehe } \\
\text { nsiveness }\end{array}$ & $\begin{array}{c}\text { Strategy's } \\
\text { Effectiven } \\
\text { ess }\end{array}$ & $\begin{array}{c}\text { Existing of } \\
\text { Strategic } \\
\text { Base }\end{array}$ & $\begin{array}{c}\text { Ongoing } \\
\text { Evaluatio } \\
n\end{array}$ & $\begin{array}{c}\text { Performa } \\
\text { nce }\end{array}$ \\
\hline \multirow{2}{*}{$\mathrm{N}$ Valid } & 207 & 207 & 207 & 207 & 207 & 207 \\
\cline { 2 - 8 } Missing & 0 & 0 & 0 & 0 & 0 & 0 \\
\hline Mean & 3.4589 & 3.7768 & 3.9589 & 4.0954 & 2.7826 & 4.0282 \\
\hline Skewness & -.611 & -.400 & -.966 & -.928 & .393 & -.850 \\
\hline $\begin{array}{l}\text { Std. Error of } \\
\text { Skewness }\end{array}$ & .169 & .169 & .169 & .169 & .169 & .169 \\
\hline Kurtosis & -.290 & -.094 & .115 & -.044 & .233 & -.509 \\
\hline $\begin{array}{l}\text { Std. Error of } \\
\text { Kurtosis }\end{array}$ & .337 & .337 & .337 & .337 & .337 & .337 \\
\hline
\end{tabular}

\section{Findings of Data Analysis}

This section concerned with analysis, findings and interpretation of data that conducted to answer the research questions and test its hypothesis. The data analysis for the current study is done via SPSS and Excel software program in order to answer the research questions and test its hypothesis. The reliability test for the measurement tool assessed by Cronbach's Alpha and Guttmann split-Half Method. Cronbach's Alpha values ranged above 0.590 , and the overall value was 0.932, and Guttmann Split-Half Coefficients of the questionnaire's dimensions ranged above (0.652) except "Ongoing Evaluation", and the overall value was (0.900) which considered an excellent level of internal consistency of the questionnaire.

According to table (7) shows that all variables had high satisfaction level, accept ongoing evaluation that had a mean of (2.80) and SD. (0.905) indicating that participants think it makes government organizations face challenge to have successful strategic planning.

Table (7) Descriptive Statistics of all Questionnaire Axis

\begin{tabular}{|c|l|c|c|c|c|}
\hline No. & The Questions of First Axis & Analysis N & Mean & Std. Deviation & Decision \\
\hline 1 & Extent of Planning & 207 & 3.4589 & .92242 & High \\
\hline 2 & Strategy's Comprehensiveness & 207 & 3.7768 & .72557 & High \\
\hline 3 & Strategy's Effectiveness & 207 & 3.9589 & .79524 & High \\
\hline 4 & Existing of Strategic Base & 207 & 4.0785 & .73541 & High \\
\hline 5 & Ongoing Evaluation & 207 & 2.8019 & .90543 & Medium \\
\hline 6 & Performance & 207 & 4.0250 & .98836 & High \\
\hline
\end{tabular}

The Table (8) shows descriptive statistical analysis of the general information of study sample for Gender, Qualification, Job Position, Service Years and Ministry found by frequencies and percentiles. The results indicate that demographic characteristics of the Study Sample consist of 207 employees from the eight selected Ministries. Male participants were 129 (62.3\%) compared to 78 females $(37.7 \%)$. The highest percentiles of respondents holding bachelor degree 
representing $60.4 \%$. There are $36.2 \%$ staff for the variable of job position. While the highest value of service years' variable was $39.6 \%$ for (6-10 years) experience and there are (19.3\%) participant from Ministry of Municipalities as a highest value for variable of Ministry.

Table (8) highest percentiles of each variable

$\begin{array}{lccccc}\text { Variable } & \text { Ministry } & \text { Gender } & \text { Qualification } & \text { Job Position } & \text { Service Years } \\ \text { Value } & \text { Municipalities } & \text { Male } & \text { Bachelor } & \text { Staff } & 6-10 \text { Years } \\ \text { Percentile } & 19.3 \% & 62.3 \% & 60.4 \% & 36.2 \% & 39.6 \%\end{array}$

A comparison of descriptive statistics analysis for the respondents about the strategic planning and performance of the government organizations found by percentiles, means, standard deviations, satisfaction level and order. Findings show a high satisfaction level for all descriptive statistical of strategic planning and performance accept ongoing evaluation which had a medium satisfaction level with three items got low satisfaction level. Therefore, in order to test the hypothesis of the study, the researcher used Spearman-Brown Correlation Coefficient and Multiple Regression Analysis which are non-parametric tests. The all five hypothesis are accepted which assume there is a significant correlation at level .000 between the five variables of strategic planning and performance of government organizations.

Table (8) shows result of Spearman's Correlation Coefficients between independent variables and dependent variable range above (.182) since (Sig. (2-tailed) $=0.000$ ) which is less than 0.01 therefore, $(\mathrm{P}<0.05)$ indicating that the overall strategic planning significantly correlated with the outcome variable which is performance of government organizations.

\begin{tabular}{|c|c|c|c|c|}
\hline \multicolumn{5}{|c|}{$\begin{array}{l}\text { Table (9) Spearman correlation coefficient between the "extent of planning" and the } \\
\text { "Performance" of government organizations. }\end{array}$} \\
\hline No. & Hypothesis & Correlation & $\begin{array}{l}\text { Sig. } \\
\text { tailed) }\end{array}$ & Summary \\
\hline 1 & $\begin{array}{l}\text { There is a relationship between "extent } \\
\text { of planning" and "performance". }\end{array}$ & $.569 * *$ & .000 & $\begin{array}{l}\text { Statistically } \\
\text { significant }\end{array}$ \\
\hline 2 & $\begin{array}{l}\text { There is a relationship between } \\
\text { "strategy's comprehensiveness" and } \\
\text { "performance". }\end{array}$ & $.722 * *$ & .000 & $\begin{array}{l}\text { Statistically } \\
\text { significant }\end{array}$ \\
\hline 3 & $\begin{array}{l}\text { There is a relationship between } \\
\text { "strategy's effectiveness" and } \\
\text { "performance". }\end{array}$ & $.646 * *$ & .000 & $\begin{array}{l}\text { Statistically } \\
\text { significant }\end{array}$ \\
\hline 4 & $\begin{array}{l}\text { There is a relationship between "existing } \\
\text { of strategic base" and "performance". }\end{array}$ & $.702 * *$ & .000 & $\begin{array}{l}\text { Statistically } \\
\text { significant }\end{array}$ \\
\hline 5 & 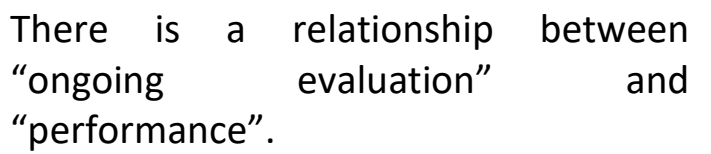 & $.182 * *$ & .000 & $\begin{array}{l}\text { Statistically } \\
\text { significant }\end{array}$ \\
\hline
\end{tabular}


Table (10) shows Multiple Regression Analysis results, that the five strategic planning factors impact the performance. If $(P<0.05)$ the regression model is statistically significant to predict outcome variable which is performance. Based on the values of $(B)$ the relationship between the variables of strategic planning and performance is positive, and the $(P)$ value is a statistically significant for all variables except the ongoing evaluation which is $(P>0.05)$.

\begin{tabular}{|l|c|c|c|c|c|}
\hline \multicolumn{7}{|c|}{ Table (10) Coefficients } \\
& \multicolumn{2}{|c|}{$\begin{array}{c}\text { Unstandardized } \\
\text { Coefficients }\end{array}$} & $\begin{array}{c}\text { Standardized } \\
\text { Coefficients }\end{array}$ & $\mathrm{t}$ & Sig. \\
\cline { 2 - 4 } & $\mathrm{B}$ & Std. Error & Beta & \\
\hline (Constant) & -1.008 & .217 & & -4.642 & .000 \\
Extent of Planning & .189 & .061 & .176 & 3.094 & .002 \\
Strategy's Comprehensiveness & .442 & .078 & .325 & 5.705 & .000 \\
Strategy's Effectiveness & .265 & .068 & .213 & 3.880 & .000 \\
Existing of Strategic Base & .395 & .083 & .294 & 4.772 & .000 \\
Ongoing Evaluation & .018 & .038 & .016 & .471 & .638 \\
\hline
\end{tabular}

Dependent Variable: Performance

\section{Contribution and Implication}

Through the current study about the strategic planning in the Sultanate of Oman, the major aspects confirm in this study are that the eighth five-year plan which considered as one of the master strategic plans for the Omani government sector practicing a high degree of strategic planning. According to the respondents' opinions of the government organizations think that the performance of government organizations positively influenced by strategic planning factors expressed by the extent of planning, comprehensiveness of strategy, the effectiveness of the strategy, existing of strategic base and ongoing evaluation. Accordingly, the current research findings help top management, executives and strategy developers to improve their organization's planning, where the process of developing the plan is well defined in a systematic way that drives the developers throughout the whole strategic planning process. This paper provides a better realization of strategic planning for the Omani government sector in order to develop and improve a solid understanding of the fundamental characteristics of strategic planning through investigating five factors of strategic planning: extent of planning, strategy comprehensiveness, strategy effectiveness, existing of strategic base and ongoing evaluation. As well as, it assists in reviewing the basic steps those government organizations follow when implementing the strategic planning. Therefore, strategy developers in government organizations in Oman may benefit from this study in reviewing and organizing their strategic plans in a better way, through which the process of developing the strategic plan is explained in its various stages, in a systematic way, it leads government organizations to develop successful strategies for them.

\section{Limitation of the Study}

There is no study free from weakness, therefore all researches have limitations, Limitations often handled with hesitancy, where some people wish to ignore the matter, feeling that showing of limitations detracting the importance of the study (Donald \& Pamela, 2014, P: 539). Although the 
study tries to ensure that the developed conceptual model and hypotheses are created carefully and developed from a strong theoretical background, the current study acknowledges the presence of some limitations. The researcher thinks that the absence of mutual dialogue with respondents while collecting data via questionnaire considered as weakness that could be improved by collecting data vi a personal interview with concerned employees. Whereas, through interview scan write down more notes, receives more ideas and get further suggestions about strategic planning issues. Because of the limited time, the study population comprise employees of planning departments of eight ministries, that makes the study loss a big number of executives and general managers from government and public entities who responsible for developing strategies and plans in their organizations. Experimental data collected from the head offices of eight government ministries located in the territory of Muscat and did not include other directorates of the same ministries. Therefore, the results of this study are limited to a small part of governmental units, and thus cannot be generalized to other parts of the same country or other states.

\section{Conclusion and Recommendation}

Based on the analysis of the data and the results of the study, the researcher believes that there are some important aspects associated with strategic planning that need to be reinforcement, to further activate of strategic planning role in Omani government organizations, to enhance the institutional role in these organizations in the future. The researcher recommends the continues to employ strategic planning systematically in all government organizations in the sultanate of Oman, as a management tool that helps organizations to achieve their future goals on a regular basis. The organization must allocate sufficient financial and human resources to help in implementing the strategies adopted by the organizations of the government sector. Continue the review and amend the strategic plans of the government sector periodically, in order to maintain good performance during the implementation phase. Government organizations should take into account the positive outcomes of strategic planning in improving their performance. The strategic planning is widely used by organizations at the international level, as it is an integral part of a strategy and it's a formal consideration of an organization's future course (Bradford and Duncan, 2000). The strategic planning is designed to help organizations to respond effectively to their new situations. As well it focuses on organizational attention on what is actually is important for the survival, growth, and effectiveness of the organization and provides useful advice on how to achieve these aims. Furthermore, most strategic planning help in identifying the consequences of failure to address the issues facing the organizations (Alshamsi, et al., 2020; Bryson, 1988). The strategic planning is an organizational management process used to analyze the current situation of an entity, to determine priorities, and to focus resources and energy on achieving and maintaining a competitive advantage for the entity itself (Ong, 2015). Government organizations have to pay more attention to provide comprehensive and integrated strategies that contributing in improving organizational performance. Whereas, comprehensive strategic planning contributes towards better organizational performance. Meaning institutions that focus on rational and comprehensive strategic planning have better performance indicators on those less focusing on the mentioned process. Therefore, organizations with a strong emphasis on comprehensive and integrated planning pay significant attention to strategy implementation (Khoshtarialn Tornike, 2018). Furthermore, the necessity of linking the comprehensive strategic 
planning to each other to achieve the cumulative build-up, which reflects positively on the efficiency of institutional performance in the long run (Al-Harethi \& Al-Maamari, 2018). Government organizations must pay more attention to the restructuring planning process. Characteristics that are essential for successful strategic restructuring include wide communication at all levels, immediate support from top management, common organizational mission and vision, strong staff group, and self-confidence (Kohm \& LaPiana, 2003). Core activities in strategy implementation are resource allocation, restructuring process, and the changing of organizational culture to facilitate the implementation of planned activities. As a result, the ultimate product developed at the end of this task is the differential realization of strategies in various forms (Singh, 2005). Government organizations should provide a solid strategic foundation that allows for successful implementation of strategic planning. The existence of a strategic base of the organization has been explained by the availability of strategic foundation in an organization which cover vision, mission and short-term and long-term goals (Salkic, 2014). The strategic base exists when all managers get the opportunity to create their own personal mission, vision, and key objectives. Thus, organization's mission, vision and objectives are specified process of the strategic management to develop policies and plans for the projects and programs, which are prepared to achieve these objectives, through allocating resources and implementing the policies and plans (Direction, 2013). Government organizations should provide clear rules and policies that help in evaluating strategies and plans to ensure achieving strategic goals and avoid mistakes in the future. The process of strategic planning involves of three main stages which are; formulation, implementation, and evaluation (Andrews, 2003). While the last stage in the strategic planning process is strategy evaluation and control. Successful evaluation of strategy begins with defining the parameters to be measured, where it includes performance measurements, consistent review of internal and external issues and making corrective actions when necessary (Jim Clayton, 2018). The clear rules and policies help to know what the firm wants to achieve and will have criteria for evaluating various courses of action (Institute of Chartered Accountants of Bangladesh, 2009: 86).

\section{References}

Abdalkrim, G. M. (2013). The impact of strategic planning activities on private sector organizations performance in Sudan: An empirical research. International Journal of Business and Management, 8(10), 134.

Ahmed, Y. (2011). The eighth five-year plan in Oman creates 275,000 job opportunities. albayan. available at: https://www.albayan.ae/economy/discussion/2011-12-12-1.1553261, Accessed on 12.09.2020

Aileron. (2011). 10 Reasons Why Strategic Plans Fail. Available at: https://www.forbes.com/sites/aileron/2011/11/30/10-reasons-why-strategic-plans-fail/\#

Akinyele, S. T., \& Fasogbon, O. I. (2010). Impact of strategic planning on organizational performance and survival. Research Journal of Business Management, 4(1), 73-82.

Al Kaabi, O. M. S. M., Karim, A. M., Hossain, M. I. (2019). Evaluation of Budgetary Control due to Fluctuation of Petroleum Price on Ministry of Interior, UAE: A Framework of Analysis. International Journal of Academic Research in Business and Social Sciences, 9(5), 698 - 716.

Alalade, S. Y., \& Oguntodu, J. A. (2015). Motivation and Employees Performance in the Nigerian Banking Industry. International Journal of Economics, Commerce, and Management, 3(4). 
Al-Harethi, A. A. M., \& Al-Maamari, Q. A. (2018). The Impact of Strategic Planning on Improving Institutional Performance at Limkokwing University of Creative Technology in Malaysia. International Journal of Psychology and Cognitive Science, 4(3), 112-129.

Al-Harrasi, F. S. (2019). The extent of practicing strategic planning by basic educational school principals in the Sultanate of Oman schools. Journal of Islamic Educational Research (JIER), 4 (1).

Alkaabi, A. K. A. S., Adaikalam, J., Karim, A. M., Hock, O. Y., \& Hossain, M. I. (2020). Influence on Internal Control through Digitalization of Assets: A Study on Ministry of Interior, UAE. International Journal of Academic Research in Accounting, Finance and Management Sciences, 10 (1): 13-24.

Al-Limon, N. A. (2014). The reality of strategic planning in general education schools In Abu Dhabi Educational Zone. Journal of the University of Damascus, 30 (2).

Al-Mashrafi, H. (2002). Economic growth in the sultanate of Oman 1971-2001. Master dissertation. University of Exeter. UK

Alperstein, G., Sainsbury, P., \& O'Grady, S. (2008). Implementing a strategic plan for child health: A Sydney case study. Journal of paediatrics and child health, 44(11), 630-635.

Al-Saidi, A. (2010). The Strategic planning and its relationship to Organizational performance effectiveness: An Empirical Study on Information Technology Companies in Sultanate of Oman. Master thesis. UK: International Virtual University.

Alshams, Y. A. A. B., Hock, O. Y., Karim, A. M., Hossain, M. I. (2019). Developing a Framework on Performance and Challenges of Strategic Management Information System: A Case study on Ministry of Interior, UAE. International Journal of Academic Research in Business and Social Sciences, 9(5), $\quad 633-646$.

Alshams, Y. A. A. B., Adaikalam, J., Karim, A. M., Hock, O. Y., \& Hossain, M. I. (2020). Application of Strategic Management Information System (SMIS) in the Ministry of Interior, UAE: Issues and Challenges. International Journal of Academic Research in Business and Social Sciences, 10(2), 346-361.

Andersen, T. J. (2000). Strategic planning, autonomous actions and corporate performance. Long range planning, 33(2), 184-200.

Andrews, K. R. (2003). The concept of corporate strategy. The strategy process: Concepts, contexts, cases Upper Saddle River, NJ: Prentice Hall.

Arab Organization for Administrative Development (ARADO) (2001). Experiences of development and administrative reform in the Arab world. Chapter Nine: Oman's experience in administrative development, themes, achievements and challenges. Retrieved from: http://notes1.etf.europa.eu/eventsmgmt.nsf/(getAttachment)/EE1ED4A9C969B840C1257 A8E004B6E53/\$File/ARADO\%20Profile.pdf

Arabian Business. (2011). The Eighth Five-Year Plan, various objectives for the Omani economy. available at: https://arabic.arabianbusiness.com/business/constructionindustry/2011/feb/17/50686, accessed on 12/09/2020

Asamoah, E. O. (2006). The impact of strategic planning on performance of district Assemblies in Ghana: case study of Ahanta West District Assembly. Master Thesis. Blekinge Institute of Technology. Sweden.

Baker, G. A., \& Leidecker, J. K.(2001). Does it pay to plan: Strategic planning and financial performance. Agribusiness, 17(3), 355-364. 
Batra, S., Sharma, S., Dixit, M., \& Vohra, N. (2016). Measuring the effectiveness of strategic planning: proposing a second order operationalization. Measuring Business Excellence. 20(3), $15-25$.

BBC News. (2017). Oman Country Profile. 30 April 2017. Middle East. Available at: http://www.bbc.com/news/world-middle-east-14654150

Boyd, B. K., \& Reuning-Elliott, E. (1998). A measurement model of strategic planning. Strategic management journal, 19(2), 181-192.

Bradford, R. W., \& Duncan, P. J. (2000). Simplified Strategic Planning, Chandler House Press.

Brewer, P. D., Brewer, V. L., \& Hawksley, M. (2000). Strategic planning for continuous improvement in a college of business. The Mid-Atlantic Journal of Business, 36(2-3), 123.

Bryson, J. M. (2004). Strategic Planning for Public and Non-Profit Organizations: A guide to strengthening and sustaining organizational achievement, 3rd edition, Jossey-Bass, San Francisco.

Bryson, J. M. (1988). A strategic planning process for public and non-profit organizations. Long range planning, 21(1), 73-81.

Bryson, J. M. (2010). The Future of Public and Non-profit Strategic Planning in the United States. Public Administration review. University of Minnesota

Bryson, J. M., \& Roering, W. D. (1988). Initiation of strategic planning by governments. Public administration review, 995-1004.

Campbell, R. (2010). Strategic Planning and Organization Performance in a Volatile Economic Environment. PhD Dissertation. School of Business and Technology. Capella University

Clayton, J. (2018). Five stages strategic management process, Small business. Available at: https://smallbusiness.chron.com/five-stages-strategic-management-process-18785.html. Accessed on 3/9/2018

Courtney, H., Kirkland, J., \& Viguerie, P. (1997). Strategy under uncertainty. Harvard Business Review, 75(6), 67-79.

David, F. R.( 2011). Strategic management concepts (13th ed.). Upper Saddle River, NJ: Pearson Education.

Direction, S. (2013). Better strategic planning: Managing change and planning for the future require both vision and strategy. Strategic Direction. 29(1), 3032. https://doi.org/10.1108/02580541311285410

Donald R. and Pamela S. (2014). Business research methods, eleventh edition. New York: McGraw-Hill Irwin

Duncan, H. (1990). Strategic planning theory today. Journal of Optimum, 20(4), 63-74.

Eadie, D. C. (1983). Putting a powerful tool to practical use: The application of strategic planning in the public sector. Public administration review, 43(5), 447-452.

Elbanna, S. (2008). Planning and participation as determinants of strategic planning effectiveness: evidence from the Arabic context. Management Decision. 46(5), 779796. https://doi.org/10.1108/00251740810873761

Fwaya, O. (2006). Human Resource systems and competitive strategies in hospitality organizational performance. Kisumu: Maseno University.

Geoffrey, M., David, D., \& David, F. (2005). Essentials of Research Design and Methodology. John Wiley \& Sons, Hoboken, Canada. 
Glaister, K. W., \& Falshaw, J. R. (1999). Strategic planning: still going strong?. Long range planning, 32(1), 107-116.

Gopal Sagaran. (2017). Business research a practical approach, CreateSpace Independent Publishing Platform.

Greener, S. (2008). Business Research Methods; Dr. Sue Greener and Ventus Publishing Aps.

Haden, K. (2010). Five Common Challenges to Strategic Planning. Available at: https://www.aalgroup.org/newsletter/?p=279 N.

Hamel, G., \& Prahalad, C. K. (1994). Competing for the Future; Breakthrough Strategies for Seizing Control of your Industry and Creating Markets of Tomorrow, Harvard Business School Press, Boston, MA.

Hill, J. D., \& Warfield, J. N. (1972). Unified program planning. IEEE transactions: System, man and cybernetics, 2(5), 610-621.

Institute of Chartered Accountants of Bangladesh. (2009). Business strategy. professional stage application level. Partener in learning, England \& Wales

Isaka, K., Makihara, Y., \& Pereda, S. (2010). Barriers and Assets for Sustainability in Japanese Organizations. Master Thesis. Blekinge Institute of Technology Karlskrona, Sweden.

Jamadar, Y., San, O. T., Abdullah, A. A., and Kamarudin, F. (2021). Earnings and discretionary accruals. Managerial and Decision Economics. Doi: https://doi.org/10.1002/mde.3391

Kabiru, F. C., Theuri, M., \& Misiko, A. (2018). The influence of planning on the organizational performance of agricultural state owned corporations in Kenya. International Academic Journal of Human Resource and Business Administration, 3(1), 68-80, et al. 2018

Kéchichian, J. A. (2008). A vision of Oman: State of the sultanate Speeches by Qaboos bin Said, 1970-2006

Khaled, A. S., Ahmed, S., Tabash, M. I., Al-Homaidi, E. A., \& Hossain, M. I. (2019). The Impact of Technological and Marketing Innovations on Retailing Industry: Evidence of India. Journal of Reviews on Global Economics, 8, 948-957

Khoshtarialn, T. (2018). The impact of strategic planning on organizational performance through strategy implementation. Globalization \& Business. 84-89. https://www.eugb.esu.edu.ge/uploads/content/N5/5-12.pdf

Kihanya, T. (2013). Challenges Influencing the Implementation of Business Strategies in Public Sector Firms, a Survey of Parastatals in The Ministry of Agriculture. International Journal of Arts and Entrepreneurship(1), 32-45.

Kohm, A., \& LaPiana, D. (2003). Strategic restructuring for nonprofit organizations: Mergers, integrations and alliances. Westport, CT: Praeger.

Kriemadis, A. (1997). Strategic planning in higher education athletic departments. International Journal of Educational Management. 11(6), 238-247

Kumar, R. (2011). Research methodology: a step-by-step guide for beginners. UK, London, SAGE Publications

Latif, K. I., Baloch, Q. B., \& Khan, M. N. (2012). Structure, Corporate strategy and the overall effectiveness of the organisation. Abasyn Journal of Social Sciences, 5(2), 1-13.

Mashavira, N., \& Nyanga, T. (2013). Factors Mitigating Effective Performance Management in Parastatls Operating in Masvingo urban District, Zimbabwe, International Journal of Politics and Good Governance, (6) 164-173 
McKay, E. G. (2001). Strategic planning: SHATIL, Technical assistance project of the New Israel Fund. Retrieved from: https://www.hcc.edu/Documents/About/Strategic\%20Planning/Strategic\%20Planning_\% 20A\%20Ten\%20Step\%20Guide.pdf

Migwi, K., \& Mwangi, D. (2017). Strategic Planning Impact of Omani Public Institution. Retrieved from:

https://www.academia.edu/25479171/Strategic_Planning_Impact_Performance_Of_Oma ni_Public_Institutions_1

Ministry of civil services. (2017). The annual statistics of civil service employee 2016. https://www.ons.gov.uk/releases/civilservicestatistics2016

Mintzberg, H. (2007). Tracking strategies: Towards a general theory. New York, NY: Oxford University Press, USA.

Mpofu, S. (2010). Strategic Leadership Challenges in the Management of Projects in the Parastatals. Unpublished doctoral dissertation), University of the Witwatersrand, Johannesburg, South Africa.

Mukrashi, F. A. (2016). Oman government institutions face audit. [online] GulfNews. Available at: http://gulfnews.com/news/gulf/oman/oman-government-institutions-face-audit1.1655004 [Accessed 26 March 2020].

Njeri, E. (2016). Challenges Facing Implementation of Strategic Planning In Non-Governmental Organizations. A Case Study of Kenya Red Cross Society (Doctoral dissertation, United States International University-Africa).

Odhiambo, M., \& Waiganjo, E. (2014). Role of Human Capital Management Strategies on Employee Mobility in Kenyas Public Universities. A case Study of Jomo Kenyatta University of Agriculutre and Technology(JKUAT). International Journal of Business and Social Science, 5(6), 185-189.

Oman Information Center. (2001). Available at: http://www.omaninfo.com/oman/government.asp

Ong, C. (2015). Five Benefits of Strategic Planning. E-nvisio (online). Available at: www.envisio.com/blog/benefits-of-strategic-planning. Accessed on 3/10/2016

Rampersad, H. K. (1997). Strategic Management: a Visionary Approach, Kluwer Bedrijfsinformatie, Deventer.

Ray, P. K., \& Sahu, S. (1990). Productivity Measurement through Multi-criteria Decision Making, Engineering Costs and Production Economics, 20(2), 151-63.

Rea, C., Ilies, L., \& Stegerean, R. (2011). Determinants of organizational performance: The case of Romania. Management \& Marketing, 6(2), 285.

Rosenbloom, D. (1998). Public Administration: Understanding Management, Politics, and Law in the Public Sector. McGraw-Hill, New York.

Royal Decree. (2012). The establishment of the Supreme Planning Council and the issuance of its system.

http://docstore.ohchr.org/SelfServices/FilesHandler.ashx?enc=FhOD6sgqgzAhFXD9F\%2Fe KaFMm83LbFY75RhkIFGrig\%2B53mJq2AmDVeF7DqKDwKjS\%2BkNB6xEvw3\%2BXiBytHGIK D74qaKMbVdYsS2HvLavUPRItp6gcrEvKLG8hAnpQDRDhP

Rudd, J. M., Greenley, G. E., Beatson, A. T., \& Lings, I. N. (2008). Strategic planning and performance: Extending the debate. Journal of business research, 61(2), 99-108. 
Salkić, I. (2014). Impact of strategic planning on management of public organizations in Bosnia and Herzegovina. Interdisciplinary Description of Complex Systems: INDECS, 12(1), 61-77.

Sameh. (2006). Challenges for Strategic Planning in Developing Countries. General, Manufacturing Management developing countries, strategic planning, strategy. Available at: $\quad$ https://sameh.wordpress.com/2006/06/07/challenges-for-strategic-planning-indeveloping-countries/

Saunders M., Philip, L., \& Adrian, T. (2009). Research methods for business students. England, Pearson education limited.

Singh, K. K. (2005). The impact of strategic planning on superior organizational performance in nonprofit human services organizations: providing mental health services. Columbia university, United States.

Sullivan, J. J. (2006). Strategic Assessment and Plan: A Four-Phased Approach. Servant Leadership Research Roundtable. School of leadership studies, Regent University. Available: https://silo.tips/download/strategic-assessment-and-plan

Sultan Qaboos Cultural Center. (2017). The Sultanate of Oman. Available at: https://www.sqcc.org/About/The-Sultanate-of-Oman.aspx

Supreme Council for Planning. (2011). Eighth Five Year Development Plan 2011-2015. The First document

Supreme Council for Planning (SCPOMAN). (2016). Available at: http://scp.gov.om/en/Default.aspx.

Suri, P. K., \& Sushil. (2017). Planning and implementation of e-governance projects: a SAP-LAP based gap analysis. Electronic Government, An International Journal, 9(2), 178-199.

Thenmozhi, M. (2014). Strategy Formulation: An Overview. Management Science. Indian Institute of Technology Madras. https://www.docsity.com/es/strategy-formulation-6/3402143/

Ubhar Capital. (2017). Oman Strategy Report. Retrieved from: https://www.ucapital.net/pdf/Oman\%20Strategy\%202017.pdf.

UNICEF (2015). UNICEF annual report about the Sultanate of Oman. Retrieved from: https://www.unicef.org/media/50046/file/UNICEF_Annual_Report_2015_ENG.pdf

Uzel, J. M. M. (2015). Effect of Strategic Management Drivers on the performance of the hotel industry in Kenyan Coast (Doctoral dissertation).

Wright, T. (2019). Strategy Evaluation - How To Do It Correctly. Available at: https://www.executestrategy.net/blog/strategy-evaluation.

Yasin \& Ghaleb, S. (1998). Strategic Management. Dar El Bazory Publishing and Distribution, Amman.

Zaibi, R. (2014). The Impact of Strategic Planning on the Performance of Algerian Higher Education Institutions (from the Perspective of Balanced Scorecard) Case Study of Mohammed Khader Biskra University, Masters thesis, Mohammed Khaydar University, Biskra, Algeria

Zuckerman, A. M. (2000). Is strategic planning relevant anymore?. Trustee, 53(4), 26-26. 